\title{
SCIENTIFIC RESEARCHES OF GEOPOLITICAL INTEGRATION CONCEPTS OF THE BALTIC-BLACK SEA REGION
}

\author{
Roman Panchuk \\ Postgraduate Student at the Department of Regional Studies, \\ Institute of International Relations of Taras Shevchenko National University of Kyiv, Ukraine \\ e-mail: panchuk.r.m@gmail.com,orcid.org/0000-0003-0334-7176
}

\section{Summary}

The importance of the geopolitical integration concepts of the Baltic-Black Sea region is determined by the need to contain the threat from the east by uniting military forces, economic components and developing a common political course as a means of countering Russian expansion. By pursuing a common political course and integrating into the processes of the Baltic-Black Sea region (BBSR), Ukraine and its allies will be able to suppress Russia's imperialist intentions as a result of Russian expansion.

The scientific task is to study the integration concepts in the BBSR in order to change the world order in favor of ensuring security in the European space. In general, researchers consider geopolitical processes in the BBSR in three directions: geographical, political and military. The study analyzes different approaches to defining the Baltic-Black Sea region, defines the boundaries of the BBSR and implements comparative analysis of existing researches on the BBSR and integration processes taking place within it, establishes the importance of integration processes in the BBSR for the geopolitical location of forces in the world.

It is concluded that the integration processes in the BCHR take place not only in the military-political direction, but also in the economic and humanitarian ones. In the future, it is necessary to study in more detail the social and cultural areas of cooperation that may be the basis for the unification of the BBSR into a single union.

Keywords: geopolitics, integration processes, Baltic-Black Sea cooperation, regional integration.

DOI https://doi.org/10.23856/3935

\section{Introduction}

Recently, with the intensification of Russian aggression, the question of finding ways to develop national security strategies for both Ukraine and the EU has arisen. Therefore, the number of scientific works and analytical studies on the need to integrate Ukraine into the alliance with the Baltic-Black Sea region as a profitable partner is currently increasing. However, all scientific developments are mainly related to the military-political aspect, and a comprehensive analysis has not yet been developed. In order to carry out a comprehensive analysis of integration concepts in the Baltic-Black Sea region, it is necessary to explore existing scientific developments, expand them, systematize and establish a field for further research. In general, the integration processes in the BBSR take place in all the directions: military, political, economic, social, humanitarian, but not all of them are evenly studied. The relevance of the study of integration processes in the BBSR is explained by the fact that Ukraine's cooperation with this region is very important, because with the strengthening of Ukraine's relations with the BBSR the degree of security in Europe will increase significantly and the process of Ukraine's European integration will accelerate. This is explained by the fact that intensive cooperation 
between Ukraine and the Baltic-Black Sea region will help ensure security, develop democratic values, strengthen stability, as well as increase military and defense capabilities and simplify the system of economic trade.

\section{Approaches to the definition of the BBSR}

N. Koroma (2012) focuses on the Baltic-Black Sea region in terms of geographical approach and analyzes how this factor affects the structure of the world political system, i. e. it explores how the geographical factor has influenced the formation of a politically important region. The researcher considers the Baltic-Black Sea region as a "regional system of countries that has all the characteristics of a geopolitical interface and an existing field of confrontation" (p. 53). It is such a space that has always been at the junction of several civilizations (Western and Russian) and powerful centers of power of great empires and blocs, at the intersection of major trade routes, between different geoeconomic centers and characterized by fields of confrontation. Such spaces are still called peripheries or buffer zones - that is, those that are between two warring states. At one time, this confrontation was manifested by different political orientations of East and West. The Baltic-Black Sea region, according to the researcher, can be divided into two parts depending on the direction of the vectors of its foreign policy: the first part is already a full member of the European space, i.e. a part of the European Union, and the second is determined by its foreign policy. However, some factors deter it from full European integration.

Hypothetically, it can be predicted that when the second part makes a greater contribution to becoming a full member of the European Union, it will be possible to institutionalize a military-political union in the Baltic-Black Sea region. In this case, the BBSR will no longer be just a joint buffer zone separating the two warring parties, but will take a clear position of the West with its democratic ideas and values. Also, according to N. Koroma's approach, the political factor is determined by the geographical one: the geographical one is the initial source of the formation of a certain policy. However, only after defining the West in the face of the EU and the East in the face of Russia as antagonistic forces, politicians and researchers begin to pay attention to how to resolve this confrontation based on geographical conditions. In other words, geographical location is not so much a precondition for a confrontation between the EU and Russia, but a way to resolve the political conflict caused by Russian aggression. The conflict between the West and the East is not geographically determined, its solution is geographically determined. The solution is finding a region that can act as a protective barrier in this conflict, and such a region is the Baltic-Black Sea.

The American historian Stephen Cohen asserted that the BBSR is located within the most important geostrategic zones: Maritime and Continental or Eurasian (Kolosov \& Mironenko, 2012: 104). British geopolitician G. Mackinder (2005) focused on the importance of the BBSR, because, in his opinion, it is a region of world balance. The approaches of St. Cohen and G. Mackinder differ from N. Koroma's previous approach in that researchers view the BBSR through the prism of maintaining balance, rather than through the prism of a barrier between warring parties.

From the point of view of the geographical approach, the Baltic-Black Sea region is an integral part of both the European and Eurasian spaces, which is territorially located at the epicenter of the intersection of the axes of geostrategic interests of the world. That is why such a region must determine in advance the vector of its own foreign policy orientation in order to accept internal and external challenges. According to this approach, the contradictions in this region are caused by the fact that it is simultaneously territorially located in two parts of the 
world - in Europe and Asia. That is why the BBSR must determine its political orientation in order to act by taking the side of a more stable region.

From the point of view of the political approach, the BBSR is an open regional territorial-political system of the meso-level, which can function dynamically by combining national geostrategies and form a special field of international cooperation on its territory. In general, the territory of the Baltic-Black Sea region consists of three entities: the Baltic States, Central Europe and the Black Sea region. That is, the BBSR "unites post-Soviet countries and countries from the former socialist camp; a space that continues to struggle with post-Soviet memory and tries to return to Europe" (Koroma, 2012: 56). The political approach differs from the geographical one in that it is not geography as such and the location of countries that cause possible conflicts, but the existing political system in different states creates the need to create a region that would reconcile these different and sometimes antagonistic systems.

Today, according to N. Koroma (2012), the BBSR includes the Baltic countries (Lithuania, Latvia, Estonia), Poland, the Czech Republic, Slovakia, Romania, Hungary, Ukraine, Belarus (p. 57). As the security status of this region today depends not only on the European space, but also on the entire Eurasian continent, these countries determine the political future in terms of distribution of the spheres of influence. And if they manage to contain the threat from Russia, they will be able to control the heart of Europe (Hartland according to G. Mackinder). If, on the other hand, the region fails to unite and jointly direct its actions, Europe may be divided into East and West, which will allow Russian expansion to move further West. Thus, for the most part, the security situation can be finally established at the institutional level, when non-EU countries, namely Ukraine and Belarus, will finally decide on the foreign policy vector and will take decisive action for European integration. As the role of the BBSR is to resist Russian aggression at the expense of democratic values, which is a representative reflection of EU policy, an alliance in the Baltic-Black Sea region will be possible when Ukraine and Belarus take a clear pro-European position. The role of other countries of the BBSR is also important in order to support Ukraine and Belarus more actively, and thus insist on the importance of establishing the Baltic-Black Sea Union more actively too.

Modern scientist U. Rudnytska (2015) considers the Baltic-Black Sea region as an "alternative option for cooperation" for Ukraine due to the aggravation of the relations with Russia and due to the impossibility of short-term rapprochement with the EU due to the open conflict in Donbass (p. 97). That is, the researcher considers the BBSR exclusively through the prism of the benefits that this region represents for Ukraine. From the point of view of security, U. Rudnytska (2015) notes that the the BBSR is "a favorable factor for the EU and NATO in the form of a buffer organization that separates the countries of Western Europe from Central Asia" (p. 98). U. Rudnytska's approach is characterized, first of all, by the importance of the BBSR for Ukraine, and the researcher on this basis considers the parties that can become positive for other players on the world stage - the EU and NATO.

The classic of Polish geopolitical thought E. Nebrzycki in his book "Geopolityka: strategy and borders" (1945) defined the BBSR as a space between the Baltic and Black Seas which restrains the expansion of Western Europe to the East and vice versa. According to the author, the BBSR has such a strong potential that both Eastern Russia and Western Europe will always oppose its merging into a single political body, as they will see it as a danger to themselves. In contrast to previous approaches, according to E. Nebrzycki, the BBSR acts as an independent political player, acting solely in its own interests, and not only in favor of the West during the confrontation with Russia. Ukrainian researchers V. Madison and V. Shakhov (2003) in the monograph "Modern Ukrainian Geopolitics" consider the BBSR as a geographically 
advantageous region that creates an axis of North-South relations and contributes to strengthening security in Europe. Oleg Soskin emphasizes the importance of the BBSR in the following aspects: "transport related to land freight transportation by rail; pipeline, the basis of which is the development of the international oil pipeline system and the formation of an international oil consortium; maritime transport which would involve the transformation of the Black Sea into a comprehensive transport system using the experience of maritime transport in the Baltic Sea" (Rudnytska, 2015, p. 97). Thus, not all the researchers consider the BBSR exclusively through the prism of a the political approach: V. Madison, V. Shakhov and O. Soskin see infrastructural advantages in the formation of a union on the territory of the BBSR. New NorthSouth vertical transport routes can provide not only transport preferences, but also economic and security ones, as independence from Russian transport routes is very important so that Russia has nothing to manipulate.

Researcher J. Bozhilov (2014) notes that in addition to the countries of the Baltic region, Armenia, Azerbaijan and Moldova should be involved in the BBSR, as they face similar security challenges (p. 121). J. Bozhilov (2014) defines the BBSR as "a region in which the division of interests between Russia and the European Union and NATO is taking place today. This fills the region not only with internal differences, but also makes the arena of intersection of different interests" (p. 121). The political consequence of this approach may be that there will be many contradictions within the Baltic-Black Sea Union itself. The presence of a wide range of countries within the union is a significant positive factor, but the union can be strong and fruitful in a political sense only if there are no polar differences between its member states which can only lead to a greater split. If there are countries within the Baltic-Black Sea Union that have completely opposite political priorities, such an alliance will become very vulnerable because Russia will be able to provoke a real military confrontation within such a region through propaganda and other means of information warfare. In addition, in order to have a solid foundation, the BBSR must not only be based on the interests of the EU or NATO, but also create its own program and action plan within which the policy will be implemented.

Zurab Marshania (2011) on the contrary in his dissertation defines the BBSR as "a geographically and geopolitically homogeneous entity consisting of states united by common interests and common historical past - Sweden, Denmark, Finland, Norway, Lithuania, Latvia, Estonia, Germany, Poland, Ukraine, Bulgaria, Romania, Moldova, Georgia, Azerbaijan and Armenia" (p. 11). The emphasis on homogeneity is very important for the further agenda within the BBSR because the homogeneity of the interests and ideas form a coherent foreign policy. As the researcher emphasizes the importance of a common historical past, it is important to resolve all controversial historical issues that once existed between the states of the Baltic-Black Sea region (between Ukraine and Poland, between Hungary and Ukraine, between Azerbaijan and Armenia), so that further external interference could take advantage of these weaknesses and cause a split. O. Sarnatsky and N. Myhlovets (2018) consider the BBSR as an alternative vector of cooperation for Ukraine which can be "the most effective way to preserve and strengthen the security of each country in Eastern Europe" (p. 31). Researchers include the countries between the Baltic and Black Seas in the BBSR. That is, for O. Sarnatsky and N. Myhlovets the BBSR is not an end in itself for Ukraine, but only an alternative among all possible ones. And since the prospect of eventual EU integration is not short-term, integration into the BBSRis more likely.

S. Yaremenko (2014) gives the following definition: the countries of the Baltic-Black Sea region - the countries of "Romeland or border, i.e. those in the joint zone, due to which they become not only the objects of geopolitical and geostrategic importance but also the objects of 
influence. They occupy a very advantageous economic and geographical position where trade routes run between different economic centers. Therefore, their transit position always arouses geoeconomic interest in large states or blocs of states (p. 279). S. Yaremenko (2014) includes Ukraine, Poland, Lithuania, Latvia, Estonia, Slovakia, Belarus and Moldova in the Baltic-Black Sea region. We can conclude that $\mathrm{S}$. Yaremenko represents a geographical approach similar to the approach of N. Koroma. However, unlike N. Koroma, S. Yaremenko considers the BBSR not as a subject of policy, but as an object, because he considers it to be passively exposed to external influences without building his own policy on this basis. Such an approach will not have both positive and far-sighted consequences in the future, as a region whose policy is determined only by external intervention cannot be an independent political entity with its own interests in the political arena.

Therefore, the definitions proposed by the researchers above can be divided into three groups according to the following approaches:

1. Geographical: the BBSR is an integral part of both European and Eurasian spaces, which is territorially located at the epicenter of the intersection of the axes of geostrategic interests of the world, and this determines its geostrategic position.

2. Political: the BBSR is as a regional territorial-political system and a special field of international cooperation. That is, the BBSR is a territory for resolving political conflicts and reconciling political interests.

3. Military (security): the BBSR is a region that by its location acts as a barrier and buffer zone and can ensure the security of Europe's Central and Western space. It is partly related to geography, because the need for a buffer zone stems from the fact that this region is located at the Euro-Asian junction, which means that such a geographical location predicts a dissonance of interests, and therefore there is a need for a buffer zone.

\section{The researches of the integration processes in the BBSR}

In order to move on to the subject of research - integration processes in the Baltic-Black Sea region, it is necessary to find out what the integration processes are. The famous researcher A. Solonitsky (1995) gives the following definition of the integration process - "it is a necessary condition for the civilizational development of the modern world because due to the relationship and interdependence between states there are new opportunities for social development in the latter" (p. 10). M. Nazarov and O. Makarenko define integration processes as "the union of independent states which are aware of their interdependence, into a single system" (Philosophical Encyclopedic, 1983: 210). The philosophical dictionary defines the integration processes as the processes of unification which take place both within the already created system, which leads to an increase in its level of integrity and organization, and during the emergence of a new system of previously unrelated elements. Based on this, we can offer our own author's definition: integration process in the Baltic-Black Sea region is a union of states located in an arc between the Black and Baltic Seas on the one hand and between Russia and Germany - on the other into an organized system based on common interests in order to obtain interdependent benefits. This group of countries includes Lithuania, Latvia, Estonia, Poland, the Czech Republic, Slovakia, Romania, Hungary, Ukraine, and Belarus.

Among the integration processes that were developed but never implemented, within the BBSR, first of all, is the Black Sea Doctrine of Yuri Lypa, which was proposed in 1940 as a union of countries on the principle of access to the Black Sea. Ukraine has played a leading role, as it surpasses other countries in the region in terms of territory and population. 
The following authors R. Kazankov (2008), Yu. Shmalenko (2007), S. Vasylenko (2002), Yu. Kochubey (2007), L. Domashchenko (2008), and M. Dnistryansky (2000) studied this geopolitical doctrine. R. Kazankov (2008) studied the Black Sea doctrine in terms of positive impact on industry and agriculture for the countries of the South-North axis, as well as analyzed the strategic importance of Ukraine in this vector. L. M. Domashchenko $(2007,2008)$ took as a subject of his own research not only the Black Sea doctrine of Yu. Lypa but also the concepts of M. Hrushevsky and S. Rudnytsky. In general, the author analyzed why the orientation to the Black Sea region is a priority for Ukraine. Yu. Kochubey (2007) in his work highlighted the importance of Ukraine's advance to the South: this is important not only for the purpose of guaranteeing security, but also for economic cooperation. Yu. Kochubey (2007) is convinced that the issues raised by Yu. Lypa in his work are important even now when Ukraine should integrate with the Black Sea countries into a common union. M. Dnistryansky (2000) in his work assures that the concept of Yuriy Lypa is the inclusion of Ukraine in European integration processes, as well as the state's entry into the international level where it can act as a full-fledged subject of world politics. Professor M. Holovaty (2007) defines the Black Sea doctrine as relevant to this day, and analyzes ways to implement this concept in modern realities. R. Dodonov (2005) defines the role of the Black Sea for Ukraine and compares how it differs from the significance of the Black Sea for Russia. The author insists on the importance of Ukraine's integration into the Black Sea space, but the purposes of this process are not political, geopolitical or military security factors, but the need to find a new vector of development for Ukraine after the collapse of the USSR (p. 138). Thus, according to R. Dodonov (2005), Ukraine can influence the restructuring of the world order (p. 136).

Thus, the scientific community focuses mainly on the importance of the Black Sea Doctrine in military-political as well as economic aspects. Most of the above researchers consider this geopolitical project through the prism of benefits for Ukraine, because it is central to the concept of Yu. Lypa.

From the point of view of the geographical approach S. Rudnytsky (1994) considers realization of the Black Sea doctrine, after all he studies it in the context of the river system which was geographically formed in the territory of Ukraine. In 1920, the researcher S. Rudnytsky put forward his vision of the geopolitical future of Ukraine within the Baltic-Pontic Federation, which, in addition to Ukraine, had to include Finland, Estonia, Latvia, Lithuania and Belarus. This federation differs from the concept of the Mediterranean and the Baltic-Black Sea Union in that S. Rudnytsky did not grant membership to Poland. Moreover, the researcher believed that the above countries should unite against "imperialist Poland and centralist Russia" (Rudnytsky, 1994: 154). In 1992, Zbigniew Brzezinski (1993) developed the Baltic-Pontic Doctrine. According to the researcher, the Baltic-Pontic doctrine with the formed Baltic-Black Sea Union envisages the formation of a belt that will close Russia together with its expansionist intentions in Asia and block its access to Europe.

The Intermarium project that underlies of the integration into the Baltic-Black Sea Union has been proposed in the post-Versailles era by Polish leader Józef Pilsudski to the Lithuanian, Belarusian and Ukrainian authorities with a view to establishing an interstate union (Levy, 2007, p. 166). The Baltic-Black Sea region as a platform for the implementation of the project "Intermarium" is actively considered by foreign, in particular Polish scientists. Polish researcher Marek Jan Khodakewicz (2012) in his work "Intermarium: the land between the Baltic and Black Seas" explores the Baltic-Black Sea region as the most stable part of the post-Soviet space. According to the scientist, this region is successful, but only with the active support of the United States, on which the political and economic success of the region depends 
on. With the support of the United States, the Baltic-Black Sea region is integrated into a strong alliance that will be able to suppress the totalitarian regimes of the world (Khodakevich, 2012). Polish political researcher Adam Balzer (2016) in the article "The Intermarium: between desirable thinking and real politics" analyzes the Baltic-Black Sea region, defines the geographical boundaries and basic principles of the Intermarium and notes that Western Europe and the United States are the main beneficiaries of implementation of this project. One can trace the regularity that Polish researchers mainly see the implementation of the Intermarium project with the support of the United States.

British student Ostap Kushnir (2019), on the other hand, focuses on the full value of the union without external intervention of other states: in the work "The Intermarium as a Polish-Ukrainian connection of Baltic-Black Sea cooperation" he considers the "Intermarium" through the prism of Ukraine-Poland relations and for the dominance of these two states. Romanian scientist Angela Michaela Ene (2017) in the work "World Economic Conflicts. The New American Paradigm: An Intermarium Against Russia's Destabilization Strategy" emphasizes that the initiative to unite the countries accessing the Baltic, Black and Adriatic Seas can create a safe space within Europe. Such integration, according to the researcher, will create a barrier against Russia's aggressive influence.

The report by Marlene Laruel and Ellen Rivera pays special attention to the problem of the emergence of illegal paramilitary formations in the region and the ties of radical Ukrainian nationalists with their Eastern European allies (Concept of the Intermarium, 2019), and defines the role of the Intermarium not only for Eastern countries and Central Europe, but also for the whole European Union. American Ph.D. Jonathan Levy (2006) in his dissertation "The Intermarium: East-Central European Federalism" considers the Intermarium as a separate federal structure using the concept of the tenth federalist James Madison. By developing a federal alternative to the European Union in the form of the Intermarium, according to J. Levy (2006), Eastern Central Europe can effectively pool its resources and solve security problems on its own, rather than relying on Brussels in the event of a crisis. A regional federation can be a mechanism to ensure a safe haven from conflicts in the event that the EU is unable to resolve future crises. Thus, mainly foreign researchers emphasize the importance of the Intermarium as a union that will be beneficial not only for its members which are Russia's neighbors, but also for other major global actors which are the EU and USA. They see a barrier against Russia's aggressive influence in the face of the BBSR.

Among Ukrainian researchers, L. Chupriy (2017) deals with the issue of the BBSR integration in the context of the Intermarium project. After analyzing various vectors of Ukraine's foreign policy, the author makes an accent on the south-eastern political direction, to which he directly refers the project "Middle Sea". According to L. Chupriy, the actualization of this issue is connected with the intensification of Russian expansion and finding means to counteract it. I. Todorov (2017) explores the "Intermarium" in the context of Ukrainian-American relations, where the United States plays an active role in helping Ukraine against Russian aggression. I. Todorov (2017) focuses on the integration of the Baltic States, Romania, Poland and Ukraine into a union that will become an anti-Russian center and at the same time "the center of the revival of traditional Europe" (p. 108). I. Yakovyuk (2017) in the article "The Intermarium Project: Geopolitical Analysis" explores the geopolitical situation in Central Europe, given the danger from Russia. The researcher identifies the historical path that led to the formation of the Mediterranean project, and emphasizes that Europe's influence on Ukraine and Moldova has increased due to the Eastern Partnership (Yakovyuk, 2017, p. 458). A. Goltsov (2016) in his article focuses on the fact that the countries of the Baltic-Black Sea region are a deterrent, 
and therefore they are developing geopolitical projects that will prevent Russia from regaining its imperial influence. According to the author, Ukraine is "most interested in the implementation of the Intermarium project" (Goltsov, 2016: 95). However, this geopolitical project can be implemented only in the face of confrontation between Europe and Russia.

Thus, Ukrainian researchers view the Intermarium not only through the prism of benefits for Ukraine, but also try to present the positive aspects for other countries that can become partners for Ukraine. This realistic position is explained by the fact that scientists understand that Ukraine itself is not able to resist Russia, and therefore try to present preferences that may be of interest to Western partners in order to provide support. It should be noted that the insufficient base of scientific development concerns socio-economic and cultural issues because the main priority of the union remains the military-political aspect due to the Russian policy of aggression for Ukraine.

The Intermarium is being studied not only by Ukrainian and Polish scientists, who are most interested in it, but also by Russian ones. However, Russian scholars view it as an oppositional utopian confederate project and, in their own assessment, emphasize its unrealistic and destabilizing goal. This is due to the fact that this project is primarily directed against Russia, and therefore it will suffer the most losses if the Intermarium is implemented. In particular, a book edited by V. Krashennikova and D. Bunevych (2020) was published in 2020, which characterizes the project Intermarium as bizarre and one that can cause chaos in Eastern Europe. Some Russian researchers consider the Intermarium as a means of counteracting Russia and the United States, representing the Baltic-Black Sea region as the United States. For example, V. Volovyi and I. Bartoshyna (2017) in the article "Security system in the Baltic region as a projection of the global confrontation between Russia and the United States" claim that the United States uses the BBSR by emphasizing the Russian threat to confront Russia. N. Dovzhyk (2018) in his dissertation "National Security of Poland in the context of Euro-Atlantic cooperation" determines the creation of the project "Intermarium" by the collapse of the Soviet Union and the desire of the former Soviet countries to redraw the map of Europe (p. 3). The Russian researcher also highlights the relations between Russia and Poland and their tensions as a precondition for the formation of the geopolitical project "Intermarium" (Dovzhik, 2018: 4). V. Mishin (2018) also explains the creation of the project "Intermarium" through the prism of Russian-Polish relations and connects the development of a geopolitical project by Poland with a negative historical memory in relation to Russia (p. 60).

Among the institutionalized associations that Ukraine has managed to integrate into are the Commonwealth of Democratic Choice, the Eastern Partnership, BLACKSEAFOR, and the BSEC. The Community of Democratic Choice is an extended version of the Baltic-Black Sea region in the Caspian, Mediterranean and Adriatic areas. The following scientists paid attention to the study of the activity of this organization: D. Belashchenko, V. Pereboev, V. Petrovsky, V. P. Vorobyov, A. A. Kazantsev, L. B. Moskvin, A. N. Mikhailenko, Ye. I. Brewer, V. I. Popov, V. M. Tatarintsev, Yu. V. Shishkov, and others. However, the Community of Democratic Choice focuses on GUAM's activities, as they are supposed to have common goals.

A. Dyrina (2019) focuses on the Eastern Partnership (EaP) and analyzes the history of the organization. A. Yazkova (2014) considers the international aspect of the EaP, V. Mironenko (2014) explores the activities of the EaP through the prism of relations with Ukraine, S. Zabelin (2014) analyzes the evolution of the idea of integration processes in the Eastern Partnership, V. Olenchenko (2014) represents the interests of the EU and the US in the Eastern Partnership. Iryna Bolhova (2016) explores the main results of the participation of states in the Eastern Partnership. Olga Chizhova (2019) analyzes the activities of the EaP and the consequences that it has for Armenia, Belarus, Georgia, Moldova and Ukraine. Vitaliy Vlah (2015) examines 
the problems and prospects of a joint venture for member states. Vyacheslav Pozdnyak (2017) focuses not so much on the Eastern Partnership itself as on the field of interaction between this program and other regional intergovernmental organizations with the participation of three states - Belarus, Moldova and Ukraine.

BLACKSEAFOR is an agreement established by the Black Sea Naval Group on April 2, 2001 to cooperate in maintaining peace and stability through mutual training. Lesia Shyshko (2015) devotes her research to the experience of cooperation in the field of security in the Black Sea under the BLACKSEAFOR agreement. The author analyzes the peculiarities of the Black Sea region, examines the complexities of international relations, security issues and the military balance to justify the emergence of BLACKSEAFOR. Peter Volten and Blagovest Tashev (2007) focused their research on BLACKSEAFOR as a successful naval initiative.

The development of economic ties in the form of joint regional projects in the field of transport and energy were developed within the framework of TRACECA, INOGATE and "Baku Supsa - Odessa - Brody". The EU needs financial and political support to really accelerate this cooperation. There are no domestic scientific papers on these programs, but Traseka and Inogate are the subject of research mainly by Caucasian and Russian researchers. Polad Orudzhov (2019) analyzes these projects through the prism of economic integration of the Turkic world. Farhad Huseynov (2010) defines the geopolitical role of Azerbaijan through the problem of relations between Azerbaijan and the European Union. Aziz Burkhanov (2007) explores the EU's strategy in Central Asia, highlighting successes and failures, focusing on transport infrastructure projects. Russian researchers K. Karatayev (2016) and Y. Kudryashov (2008) study the Eurasian transport corridors and their consequences for the countries through which they pass.

\section{Conclusions}

In summary, approaches to defining the Baltic-Black Sea region can be divided according to three criteria: geographical, political and military or security. All of these criteria are more closely related. From the point of view of the geographical approach, the BBSR is a region located at the Euro-Asian junction and is forced to face the inconsistency of the interests of the West and the East, and therefore there is a need to create a buffer zone. The political approach involves a conflict of interest between Russia and the West, which, based on its geographical location, necessitates of unifying the BBSR into an alliance capable of upholding democratic values. The military approach follows from the political one, because if the political conflict stagnates, it is possible to reach the armed level, and then there is a need to create a buffer zone.

In general, integration processes in the Baltic-Black Sea region should be understood as the unification of states located in an arc between the Black and Baltic Seas on the one hand and between Russia and Germany on the other, into an organized system based on common interests for mutual benefits. Thus, this group of countries includes Lithuania, Latvia, Estonia, Poland, the Czech Republic, Slovakia, Romania, Hungary, Ukraine, and Belarus.

In summary, it can be noted that not only Ukrainian and Polish scientists, but also European, American and Russian scientists study integration projects in the Baltic-Black Sea region. European and American researchers under the Intermarium are considering a union that will benefit not only its members, which are Russia's neighbors, but also other major global actors, such as the EU and the United States. In this way, the United States will be able to maintain its position as a world leader, and the EU will be able to avoid the spread of Russian expansion. Ukrainian researchers view the Intermarium not only through the prism of benefits for Ukraine, but also try to present positive aspects for other states that can become partners for Ukraine. 
After all, the BBSR will be able to unite in an alliance only with the support of world partners. Russian researchers are skeptical of integration within the BBSR and emphasize its destabilizing goal in order to counter the emergence of an entity that could impede the realization of Russia's imperial ambitions.

Based on the results of the study of integration processes in the Baltic-Black Sea region, it can be concluded that the most viable scenario for the implementation of the Baltic-Black Sea Union concept in modern conditions is the establishment of special cooperation to deepen economic integration and stimulate mutual investments. The concept, in its essence, meets the interests of all potential participants, because it will allow to implement the important and large-scale investment projects by joint efforts.

This cooperation should be institutionalized into intergovernmental association, there is a need for joint collective bodies that will be responsible for the strategy and coordination of cooperation, for the selection and development of joint projects, mutual control of their implementation. It is also advisable to consider setting up special commissions to resolve conflicts, combat and prevent corruption. For many countries of the Baltic-Black Sea region, corruption and inefficient governance are the crucial problems that can be solved to a great extend by joining the Baltic-Black Sea Union to jointly controlling the transparency and quality of projects implementation. As the next stage, on an economic basis, it is possible to deepen political integration and eventually to create an influential geopolitical unit, which consists of countries that are more or less similar in weight and challenges, and which together form a separate geostrategic force within Europe and in the international arena.

\section{References}

Bozhilov Y. (2014). The Black Sea Region needs new security architecture. Harvard black Sea security Program. Retrieved from: http://www.harvard-bssp.org/static/files/442/black_sea_2014.pdf

Goltsov A. G. (2016). Regionalnyy geopoliticheskiy proyekt "Mezhdumorye": perspektivy realizatsii [Regional geopolitical project "Intermarium": implementation prospects.]. Sravnitelnyy analiz lokalnogo opyta. Vzyato z: http://www.intelros.ru/pdf/Sravnitelnaya_ politika/2016_04/547-1116-1-SM.pdf. [in Russian]

Koroma N. (2012). Polityko-heohrafichni faktory formuvannia stykovykh heopolitychnykh rehioniv [Political and geographical factors of formation of butt geopolitical regions]. Visnyk KNU imeni Tarasa Shevchenka. Vziato z: http://visnyk-geo.univ.kiev.ua/wp-content/ uploads/2016/04/15-60.pdf. [in Ukrainian]

Marshaniia Z. S. (2011). Baltiisko-chornomorska systema mizhderzhavnoho spivrobitnytstva $u$ zovnishnopolitychnii stratehii Hruzii [The Baltic-Black Sea system of interstate cooperation in Georgia's foreign policy strategy]. Natsionalnyi universytet «Odeska yurydychna akademiia». Vziato z: https://core.ac.uk/download/pdf/50593861.pdf. [in Ukrainian]

Rudnytska U. (2015). Perspektyvy Baltiisko-Chornomorskoi rehionalnoi spivpratsi v umovakh ukraino-rosiiskoho konfliktu [Prospects for Baltic-Black Sea regional cooperation in the Ukrainian-Russian conflict]. Visnyk NTUU «KPI». Politolohiia. Sotsiolohiia. Pravo. Vziato z: http://visnyk-psp.kpi.ua/article/view/43711 [in Ukrainian]

Rudnytskyi S. L. (1994). Ukrainska sprava zi stanovyshcha politychnoi heohrafii [Ukrainian case from the standpoint of political geography]. Chomu my khochemo samostiinoi Ukrainy?. Lviv: Svit. [in Ukrainian]

Sarnatskyi O. P., Myhlovets N. O. (2018). Baltiisko-Chornomorske spivrobitnytstvo yak alternatyvnyi intehratsiinyi napriam dlia Ukrainy [Baltic-Black Sea cooperation as an 
alternative integration direction for Ukraine]. Derzhava ta rehiony. Vziato z: http://www. econom.stateandregions.zp.ua/journal/2018/4_2018/6.pdf [in Ukrainian]

Solonitskiy A. (1995). Mirovoye integriruyushcheye razvitiye i problemy modernizatsii nezapadnykh obshchestv [World integrating development and problems of modernization of non-Western societies]. MEiMO. 12. 9-12. [in Russian]

Todorov I. (2017). Vidrodzhennia kontseptsii Mizhmoria v konteksti ukrainsko-amerykanskykh vidnosyn [Revival of the concept of the Intermarium in the context of Ukrainian-American relations]. American Studies. Vziato z: http://www.americanstudies.history.knu.ua/wp-content/ uploads/2017/01/\%D0\%A2\%D0\%BE\%D0\%B4\%D0\%BE\%D1\%80\%D0\%BE\%D0\%B2 -\%D0\%86..pdf. [in Ukrainian]

Filosofskij enciklopedicheskij slovar [Philosophical Encyclopedic Dictionary]. (1983). Moskva: Sovet. Encikl. [in Russian]

Yakovyuk I. (2017). Proekt Mezhdumore: geopoliticheskij analiz [Intermarium Project: Geopolitical Analysis]. Academia EDU. Vzyato s: https://www.academia.edu/41726586/ ПРОЕКТ_МЕЖДУМОРЬЕ_ГЕОПОЛИТИЧЕСКИЙ_АНАЛИЗ

Yaremenkō S. G. (2014). Baltijsko-chernomorskoe prostranstvo kak geopoliticheskaya stykovaya zona: teoreticheskie aspekty [Baltic-Black Sea space as a geopolitical junction: theoretical aspects.]. Odesa: Odeska nacionalna akademiya harchovih tehnologij. [in Russian] 